\title{
Three Years Journal Of IJSTM (International Journal Of Science Technology \& Management: Inarah): A Bibliometric Analysis
}

\author{
M.Syamsul Hidayat ${ }^{1 *}$.Budi Utami \\ ${ }^{1,2}$ Universitas Islam Majapahit,Indonesia \\ ${ }^{*}$ Corresponding author: \\ Email: syamshidayat@gmail.com
}

\begin{abstract}
.
International Journal of Science, Technology \& Management (IJSTM: Inarah) is an internationally reputed journal with a Copernicus index that publishes original, peer-reviewed, and empirical research in science, technology and management. The use of technology in real business activities is often found in IJSTM journal articles. This journal has reached its 3 rd year of publication in 2019. Using bibliometric techniques, we analyze based on the journal's authors, salient topics, and the most prolific authors, including institutions and affiliated countries as well as .topic relationships between articles. In network analysis using VOSviewer software, the results of IJSTM publications based on the linkage of articles are that there are two clusters.
\end{abstract}

Keywords: IJSTM Journal, Bibliometrics, Vos Viewer

\section{INTRODUCTION}

The IJSTM journal has a broad scope. This journal publishes original work, peer-reviewed, and research into actual business and technology practices. Issues regarding key business decisions, processes, and activities in business settings and the use of real technology arise frequently in IJSTM. This journal began to be published in 2019 and has emerged as a major scientific academic outlet in the last 3 years. Several researchers, scholars, and practitioners are pursuing IJSTM for its academic excellence internationally. Dr. Arman Harahap, M.Si University of Labuhanbatu North Sumatra, Indonesia is the current Chief Editor of the journal. From its inception until 2021, the number of articles published was 295 articles.

This article provides an overview of the Journal Bibliography, which is already common, as an example(Donthu, Kumar, et al., 2020)summarizes 45 years of the Journal of Business Research,(Donthu, Gremler, et al., 2020) mapping the Journal of Service Research. Likewise (Goksu et al., 2020)perform content analysis and mapping in the CALL journal (Computer Assisted Language Learning), as well as (GaviriaMarin et al., 2018) provides an overview of 20 years in the Journal of Knowledge Management. (Donthu, 2021)Bibliometric analysis is a popular and rigorous method for exploring and analyzing large amounts of scientific data.In the Bibliometric review, the author explains in detail the number of articles, the number of citations, authors, 
institutions and affiliated countries as well as the number of clusters of linkages in the article.

\section{METHODS}

In making data, the author performs several stages, including:

a. By using Publish and perish searching for articles on Google Scholar, this is often done in conducting bibliometric analysis.

b. Using the keywords International Journal of science \& technology management (IJSTM Inarah.co.id), the authors found 308 articles

c. Selecting from 308 articles that meet the criteria for these keywords, 294 articles are generated.

While the data analysis is as follows:

a. Data analysis using descriptive analysis

That is, analyzing from excerpts of papers, basing bibliometric studies on documents cited as their intellectual basis. Affiliation, author, country of origin and the relationship of topics between articles based on titles and abstracts.

b. Analyzing Network

That is, the author analyzes the article network map using the Vos Viewer, to see the interrelationships between articles and other authors and also the number of clusters formed based on the interrelationships between these articles.(Sajovic et al., 2018),(Arifin et al., 2021)

\section{RESULT AND DISCUSSION}

\section{Descriptive of the most prominent citation articles}

From the analysis, an overview of the most cited articles from the IJSTM journal is generated from the beginning of 2019 to 2021, as shown in the following table:

Table 1. Most cited IJSTM articles

\begin{tabular}{|c|c|c|}
\hline No & Title & $\begin{array}{c}\text { Number } \\
\text { of Quotes }\end{array}$ \\
\hline 1 & Effectiveness of online learning in the COVID-19 pandemic & 102 \\
\hline 2 & Analysis of Banking Performance in The Aftermath of The Merger of \\
Bank Syariah Indonesia in Covid 19 & 45 \\
\hline 3 & $\begin{array}{c}\text { Application Design The Data Collection Features Of The Hotel Shades Of } \\
\text { Rantauprapat Using VBNET }\end{array}$ & 36 \\
\hline 4 & $\begin{array}{c}\text { Smart City Concept for Integrated Citizen Information Smart Card or } \\
\text { ICISC in DKI Jakarta }\end{array}$ & 33 \\
\hline 5 & \begin{tabular}{c} 
Technological developments in the Intelligent Transportation System (ITS) \\
\hline
\end{tabular} \\
\hline
\end{tabular}




\begin{tabular}{|c|c|c|}
\hline 6 & $\begin{array}{r}\text { The Effect OfGoods Prices And Buyer Trust On The E-Commerce Sales } \\
\text { System For Purchasing Goods Online }\end{array}$ & 11 \\
\hline 7 & $\begin{array}{c}\text { Technological developments in the Intelligent Transportation System (ITS) } \\
\text { Transportation Systems }\end{array}$ & 9 \\
\hline 9 & $\begin{array}{c}\text { Effectiveness of the E-Ticket System Using QR Codes For Smart } \\
\text { Promotion And Quality of Information At PT. Ng Tech Supplies }\end{array}$ & 7 \\
\hline 10 & $\begin{array}{c}\text { Supply liquid organic fertilizer NASA and rice husk ash to the chemical } \\
\text { properties of the soil on the tomato plant }\end{array}$ & 7 \\
\hline
\end{tabular}

Source: data processed with Publish and Perish (2021)

From the table, it can be explained that the articles that are quoted the most are: Effectiveness of online learning in the COVID-19 pandemic, with a total of 102 citations. Then next is an article with the title Analysis of Banking Performance in The Aftermath of The Merger of Bank Syariah Indonesia in Covid 19 with a total of 45 citations.

\section{Author of the most cited articles}

Meanwhile, an overview of the most prominent articles from the IJSTM journal from the beginning of 2019 to 2021, as shown in the following table:

Table 2. Authors of the most cited IJSTM articles

\begin{tabular}{|c|c|c|c|}
\hline Quote & Writer & Article Title & Year \\
\hline 102 & $\begin{array}{c}\text { AN Bahasoan, W } \\
\text { Ayuandiani, M } \\
\text { Mukhram, Aswar Rahmat }\end{array}$ & $\begin{array}{c}\text { Effectiveness of online learning in the } \\
\text { COVID-19 pandemic }\end{array}$ & 2020 \\
\hline 45 & M Yusuf, RN Ichsan & $\begin{array}{c}\text { Analysis of Banking Performance in The } \\
\text { Aftermath of The Merger of Bank Syariah } \\
\text { Indonesia in Covid 19 }\end{array}$ & 2021 \\
\hline 36 & SZ Harahap & $\begin{array}{c}\text { Application Design The Data Collection } \\
\text { Features Of The Hotel Shades Of } \\
\text { Rantauprapat Using VBNET }\end{array}$ & 2020 \\
\hline 33 & $\begin{array}{c}\text { MS Hartawan, AS Putra, } \\
\text { A Muktiono }\end{array}$ & $\begin{array}{c}\text { Smart City Concept for Integrated Citizen } \\
\text { Information Smart Card or ICISC in DKI } \\
\text { Jakarta }\end{array}$ & 2020 \\
\hline 11 & $\begin{array}{c}\text { R Suryadithia, M Faisal, } \\
\text { AS Putra, ... }\end{array}$ & $\begin{array}{c}\text { Technological developments in the } \\
\text { Intelligent Transportation System (ITS) }\end{array}$ & 2021 \\
\cline { 2 - 5 } & $\begin{array}{c}\text { ARA Nalendra, SH } \\
\text { Winarno, A Priadi, }\end{array}$ & $\begin{array}{c}\text { The Effect OfGoods Prices And Buyer Trust } \\
\text { On The E-Commerce Sales System For } \\
\text { Purchasing Goods Online }\end{array}$ & 2021 \\
\hline
\end{tabular}




\begin{tabular}{|c|c|c|c|}
\hline \multicolumn{1}{c|}{} & $\begin{array}{c}\text { R Suryadithia, M Faisal, } \\
\text { AS Putra, .. }\end{array}$ & $\begin{array}{c}\text { Technological developments in the } \\
\text { Intelligent Transportation System (ITS) }\end{array}$ & 2021 \\
\hline 9 & $\begin{array}{c}\text { T Kuncara, AS Putra, N } \\
\text { Aisyah, .. }\end{array}$ & $\begin{array}{c}\text { Effectiveness of the E-Ticket System Using } \\
\text { QR Codes For Smart Transportation Systems }\end{array}$ & 2021 \\
\hline 7 & $\begin{array}{c}\text { Nabella Elementary } \\
\text { School }\end{array}$ & $\begin{array}{c}\text { Improve Consumer Purchasing Decisions } \\
\text { Through Quality of Service, Promotion And } \\
\text { Quality of Information At PT. Ng Tech } \\
\text { Supplies }\end{array}$ & 2021 \\
\cline { 2 - 5 } & $\begin{array}{c}\text { FS Harahap, O Roswita, } \\
\text { A Iman }\end{array}$ & $\begin{array}{c}\text { Supply liquid organic fertilizer NASA and } \\
\text { rice husk ash to the chemical properties of } \\
\text { the soil on the tomato plant }\end{array}$ & 2020 \\
\hline
\end{tabular}

Source: data processed with Publish and Perish (2021)

For the author of the most cited articles are Effectiveness of online learning in the COVID-19 pandemic, this article deals with how effective online learning is in the COVID-19 pandemic. With a sample of 115 students and conducted in West Sulawesi. The number of citations for this article is 102 with the authors AN Bahasoan, W Ayuandiani, M Mukhram,Aswar Rahmat.

\section{Article Author Frequency}

With regard to the frequency or number of authors of the most articles, the authors limit a minimum of 4 articles (documents) published in the IJSTM Journal. The results can be seen in the following table:

Table 3. The maximum number of authors

\begin{tabular}{|l|l|l|}
\hline No & Writer & Frequency \\
\hline 1 & T Kuncara & 5 \\
\hline 2 & As Son & 4 \\
\hline 3 & T W. segoro & 4 \\
\hline
\end{tabular}

Source: processed data (2021)

From the table, it can be seen that $\mathrm{T}$ Kuncara wrote the most articles in the IJSTM journal, namely 5 articles, both as the main author and as a member. While AS Putra and TW Segoro each with 4 articles.

\section{Most Affiliated Institutions}

For the most affiliated institutions in the IJSTM Inarah journal, Gunadharma University, Jakarat. More details can be seen in the following table:

Table 4. The highest number of institutions

\begin{tabular}{|c|l|c|}
\hline Institution & district & Amount \\
\hline Gunadharma University & Jakarta & $\mathbf{1 0}$ \\
\hline
\end{tabular}




\begin{tabular}{|c|c|c|}
\hline $\begin{array}{l}\text { Faculty of Computer, STMIK Insan Pembangunan, } \\
\text { Indonesia }\end{array}$ & Jakarta & 5 \\
\hline $\begin{array}{l}\text { Hotel Management Lecturer, Tourism, Jakarta } \\
\text { International Polytechnic }\end{array}$ & Jakarta & 2 \\
\hline $\begin{array}{l}\text { Graduate Study of ICT, Asia E University, } \\
\text { Malaysia Wisma Subang Jaya, No.106, Jalan SS } \\
\text { 15/4, } 47500 \text { Subang Jaya, Selangor, Malaysia }\end{array}$ & Selangor, Malaysia & 2 \\
\hline $\begin{array}{l}\text { The Key Laboratory of Feed Biotechnology of } \\
\text { Ministry of Agriculture, National Engineering } \\
\text { Research Center of Biological,,Feed Research } \\
\text { Institute, Chinese Academy of Agricultural } \\
\text { Sciences }\end{array}$ & Beijing,China & 2 \\
\hline $\begin{array}{l}\text { Agrotechnology Study Program, Faculty Of } \\
\text { Science And Technology, Labuhanbatu University }\end{array}$ & Medan & 2 \\
\hline $\begin{array}{l}\text { Undergraduate Study Program in Applied Nursing } \\
\text { at the Health Polytechnic of Palangka Raya, } \\
\text { Indonesia }\end{array}$ & Palangkaraya & 2 \\
\hline
\end{tabular}

Source: data processed with Publish and Perish (2021)

\section{Affiliated countries}

Countries affiliated with this IJSTM journal, among others, can be seen in the following table:

Table 5. The largest number of countries

\begin{tabular}{|l|l|}
\hline Country & Amount \\
\hline Indonesia & 290 \\
\hline Beijing, China & 2 \\
\hline India & 1 \\
\hline Malaysia & $\mathbf{1}$ \\
\hline
\end{tabular}

Source: data processed with Publish and Perish (2021)

From the table, Indonesia is the country with the most affiliated with 290 articles, then China 2 articles, India 1 article and Malaysia 1 article. In the future the number of countries can increase even more, considering the age of the IJSTM Journal is still 3 years old.

\section{Network analysis}

a. IJSTM article grouping

Based on the bibliograph(Kessler, 1994) explain that scientific work can show intellectual similarity through their reference pattern. If there are two articles citing the same third article, it can be interpreted that the two articles discuss and emphasize the 
same discussion. Bibliographic analysis of 294 IJSTM works consists of 2 main clusters. Table 5 explains about IJSTM clusters, including the main focus and the most cited publications in each cluster

Table 6. Number of Authors with the Most Quotations

\begin{tabular}{|l|l|l|c|l|}
\hline Writer & Institution & Country & Number of Quotes & Year \\
\hline $\begin{array}{l}\text { AN Bahasoan, } \\
\text { W Ayuandiani, } \\
\text { M Mukhram, .. }\end{array}$ & $\begin{array}{l}\text { Faculty of Economics, } \\
\text { University of West } \\
\text { Sulawesi, Majene, West } \\
\text { Sulawesi }\end{array}$ & Indonesia & 102 & 2020 \\
\hline $\begin{array}{l}\text { M Yusuf, RN } \\
\text { Ichsan }\end{array}$ & $\begin{array}{l}\text { Panca Budi University of } \\
\text { Development }\end{array}$ & Indonesia & & \\
\hline SZ Harahap & Labuhanbatu University & Indonesia & 35 & 2021 \\
\hline $\begin{array}{l}\text { MS Hartawan, } \\
\text { AS Putra, A } \\
\text { Muktiono }\end{array}$ & $\begin{array}{l}\text { Krisnadwipayana } \\
\text { University }\end{array}$ & Indonesia & 33 & 2020 \\
\hline
\end{tabular}

Source: data processed with Publish and Perish (2021)

\section{b. IJSTM Article Writer Cluster}

From the results of the analysis with the criteria for the number of authors at least 3 and the number of documents published at least 3 as well as from the article abstract, it has been formed into 2 clusters that have a relationship, namely Cluster 1: $\mathrm{T}$ Kuncara, AS Putra and Cluster 2: W Segoro

For more details can be seen in the following table:

Table 7. Number of Authors with the Most Quotations

\begin{tabular}{|c|c|}
\hline cluster & Name \\
\hline & \\
\hline 1 & T Kuncara, As Putra \\
\hline 2 & W Segoro \\
\hline
\end{tabular}

Source: Data Processed (2021)

\section{c. IJSTM Article Writer Cluster Mapping with Vos Viewer Software} Network Visualization

network visualization can be described in Figure 1. Where the closeness between the two journals in the visual can show the relationship related to the journal with citations. In general, the closer two journals are to each other, the closer the relationship, the larger the line. 


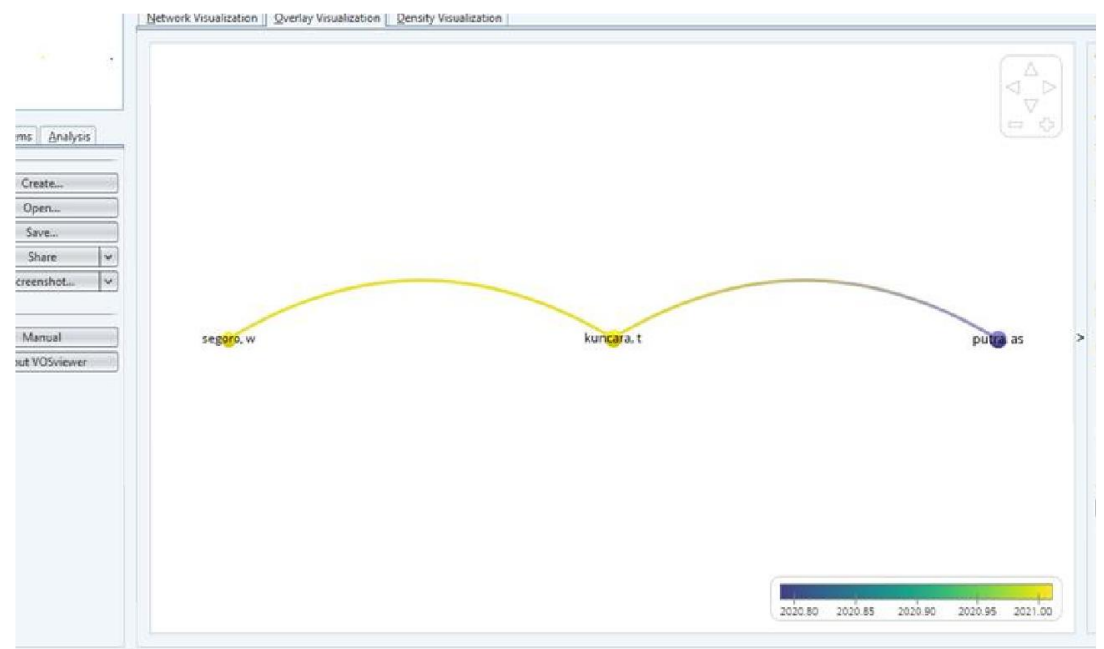

Linkage network image

From the picture, it shows that the network linkage includes 3 article authors, namely $\mathrm{T}$ Kuncara, AS Putra and Kluster and W Segoro.

\section{Density Visualization}

Based on the article (van Eck \& Waltman, 2010)in discussing the technical implementation of density visualization. In the visual image, it can be explained by the color in the visual. Where the color of the image is from blue to green to yellow. The larger the number in the area around the dot, the higher the weight, the closer the color to the yellow dot, the smaller the number of links, the closer the blue color. This can be seen in Figure 1 below.

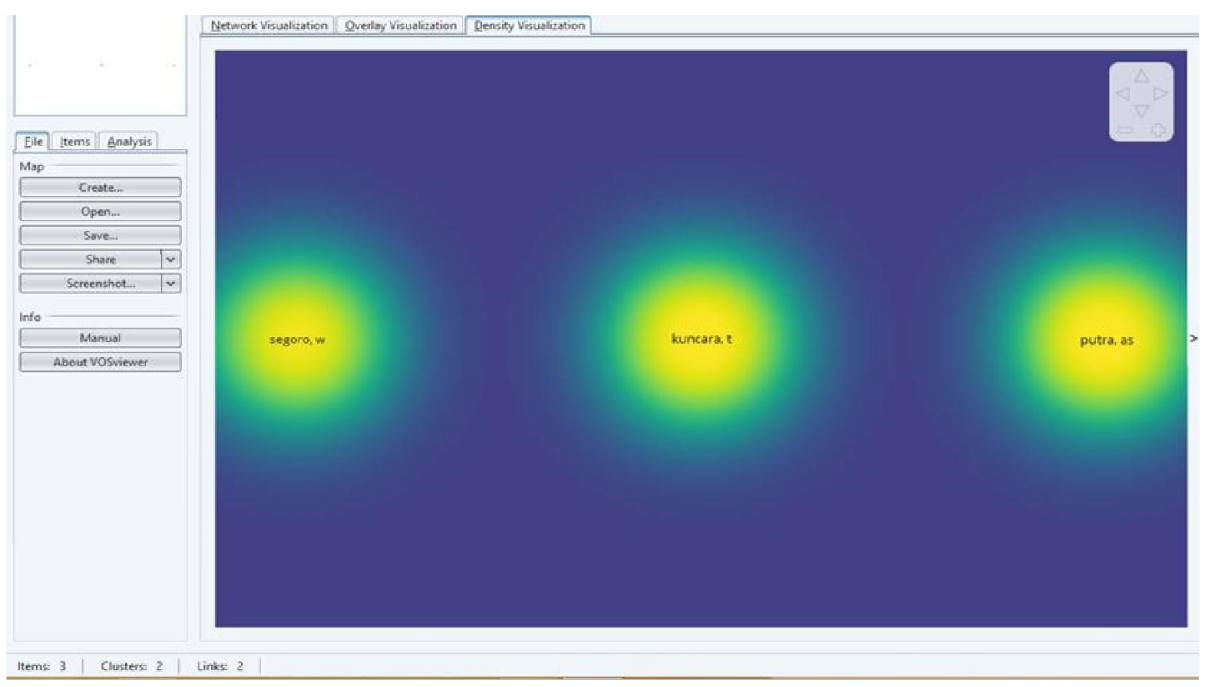




\section{d. IJSTM Article Topic Cluster}

From the results of the analysis based on the relationship between the topics of research articles published in the IJSTM Journal, it has been formed into 4 clusters, namely Cluster 1: T Kuncara, AS Putra and Cluster 2: W Segoro

For more details can be seen in the following table:

Table 8. Clusters of Article Topics

\begin{tabular}{|c|c|}
\hline Cluster & Topic \\
\hline 1 & Covid:Education,level,pandemic,patient,person,type \\
\hline 2 & Activity : Farmer, Process, level, and Use. \\
\hline 3 & Company :Impact,Management,level, Manager \\
\hline 4 & Case Study : Development, Role. \\
\hline
\end{tabular}

Source: Data Processed (2021)

\section{e. IJSTM Article Topic Cluster Mapping with Vos Viewer Software} Network Visualization

network visualization can be described in Figure 1. Where the closeness between the two journals in the visual can show the relationship related to the journal with citations. In general, the closer two journals are to each other, the closer the relationship, the larger the line.

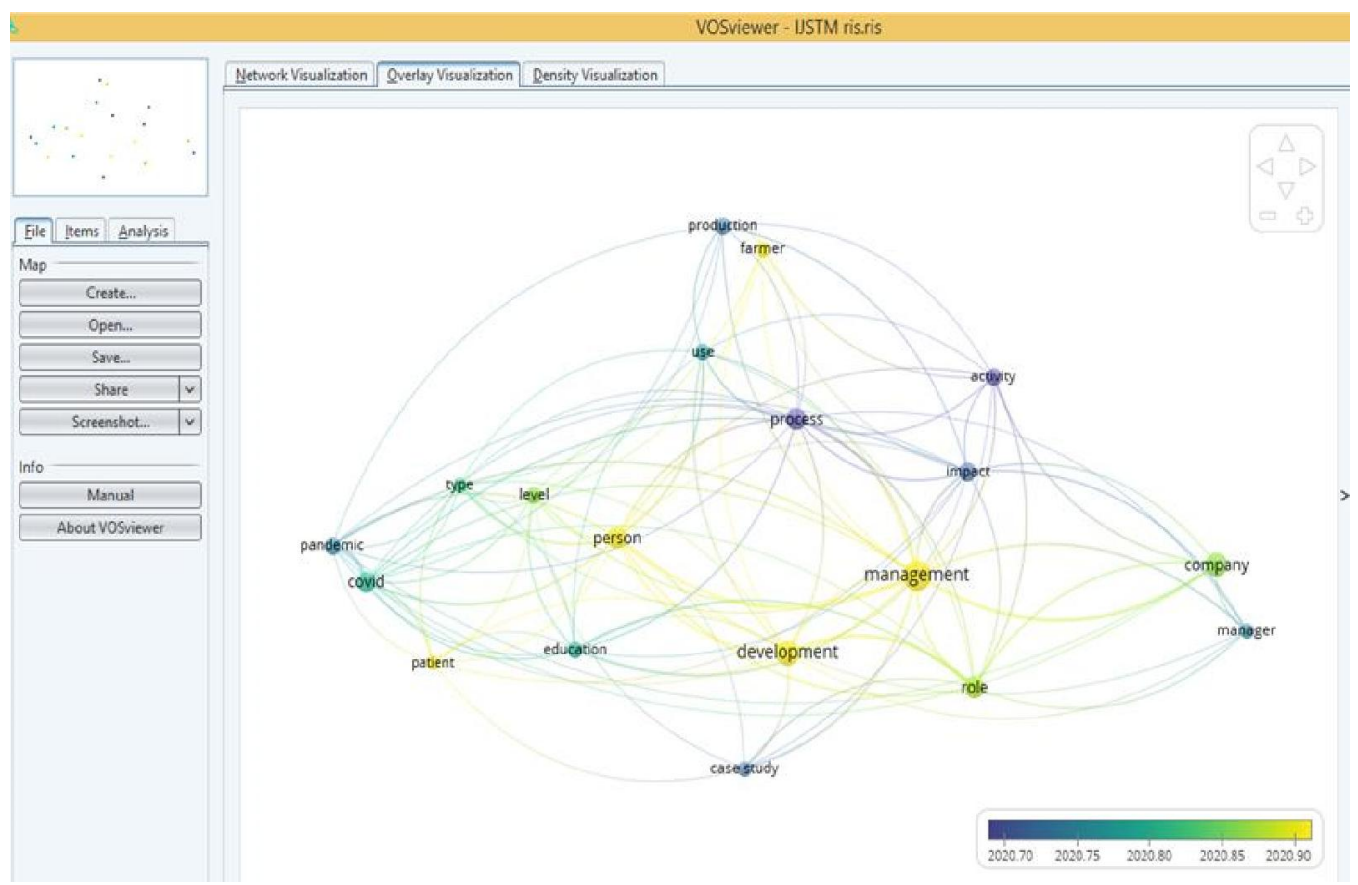

Fig 1.Overlay Visualization 
While Based on the article (van Eck \& Waltman, 2010), When discussing the technical implementation of density visualization. Visual images can be explained by visual colors. Image colors range from blue to green to yellow. The higher the number around the point, the heavier the weight, the closer the color is to the yellow point, the fewer links, and the closer to blue. This can be seen in Figure 1 below.

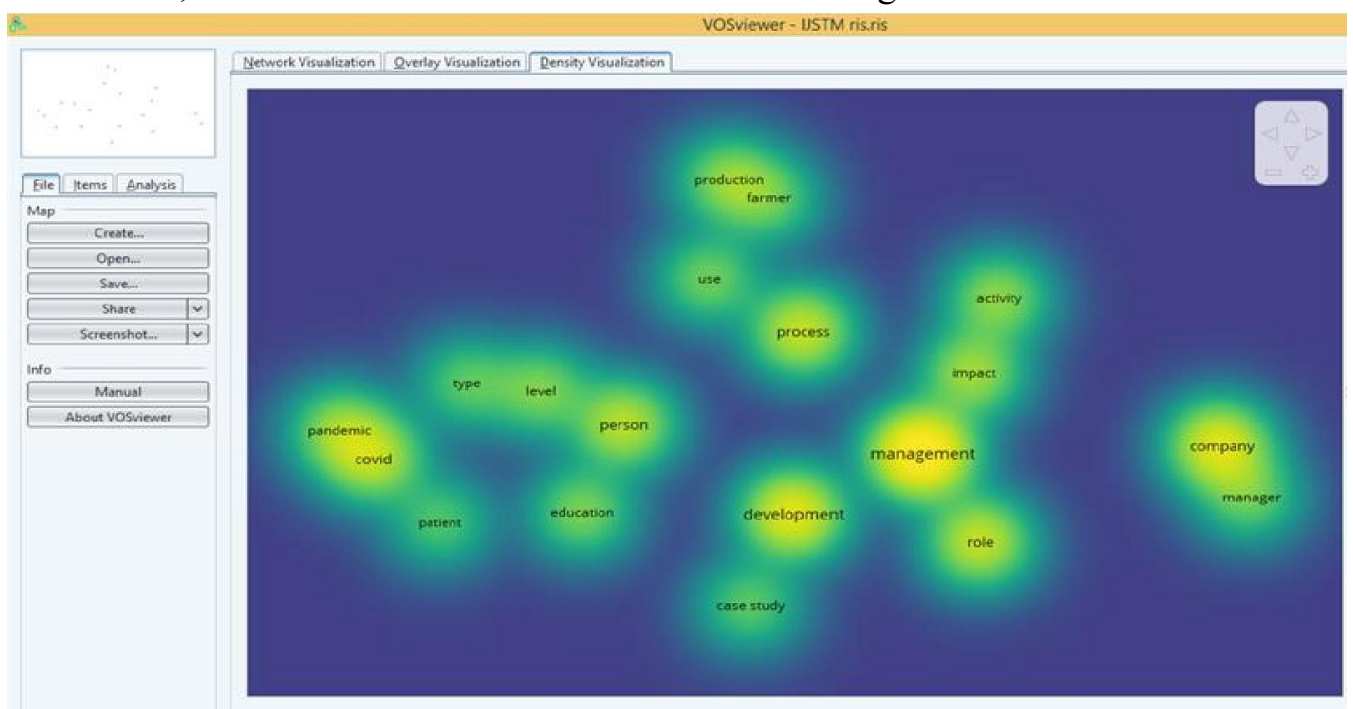

Fig 2.Density Visualization

From the picture, with Viosviewer analysis, it can be grouped into 4 article topics in IJSTM journal publications, including:

\section{Cluster 1: Covid}

Cluster 1 is the topic of the Covid pandemic, while the closest relationship to this covid is the topic of Education, level, pandemic, patient, person, type.

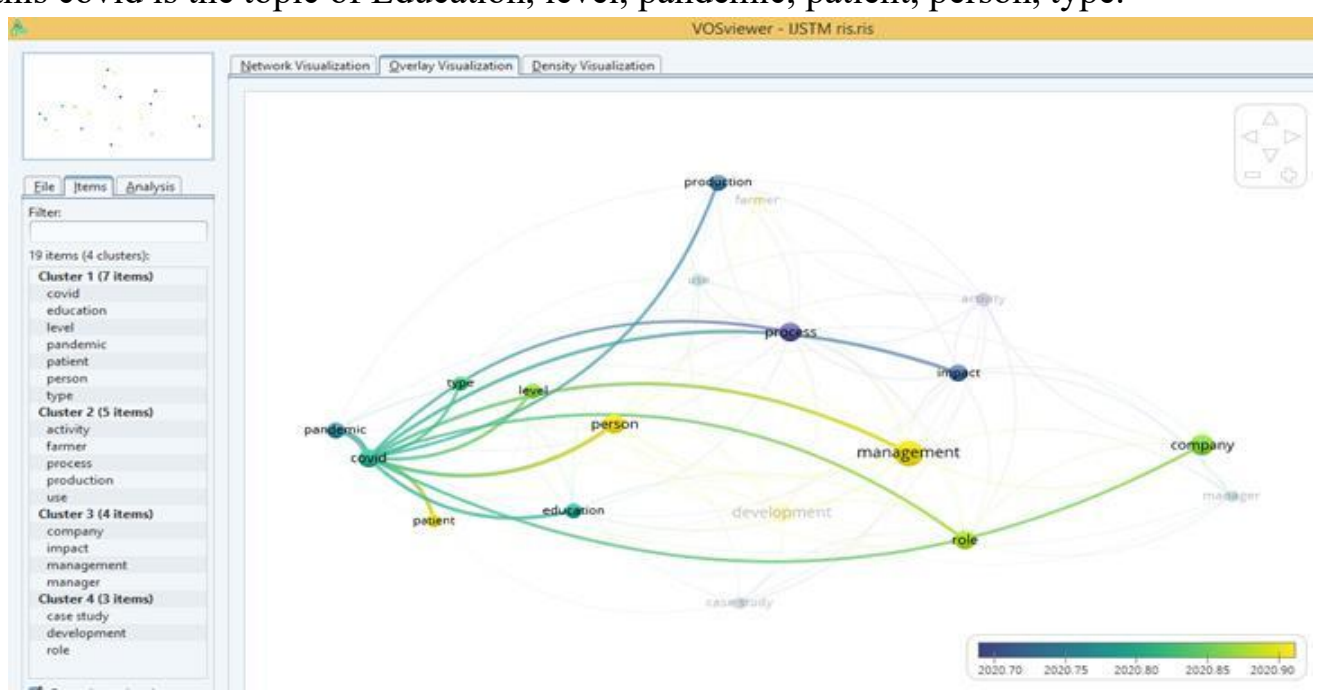

Fig 3. Cluster 1: Covid 


\section{Cluster 2: Activity}

Cluster 1 is the topic about Activity. In cluster n2, the topic closest to this activity is the topic of Farmer, Process, Level, and Use.

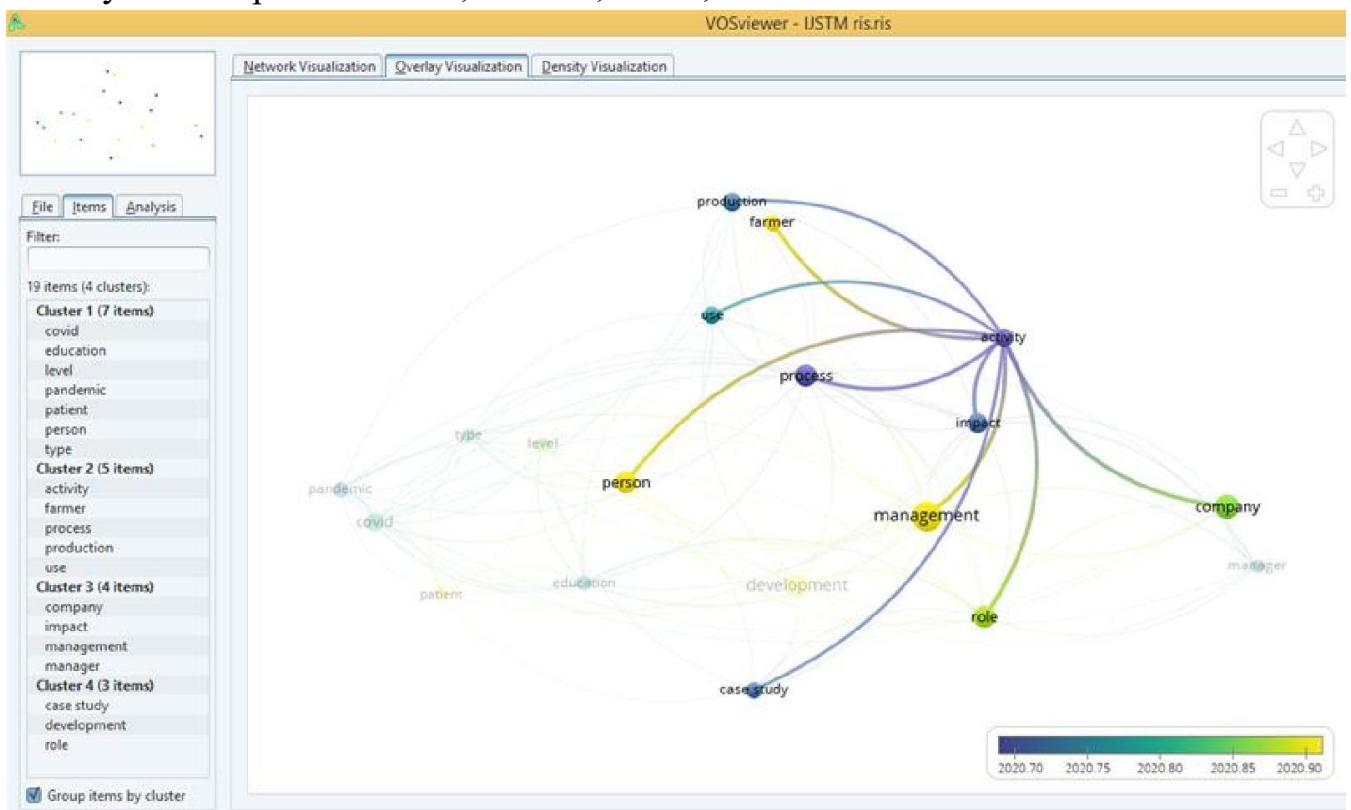

Fig 4. Cluster 2: Activity

\section{Cluster 3: Company}

In Cluster 1, the topic is about Activity. In Cluster 3, the topic closest to the Company is the topic of Impact, Management, Level, and Manager.

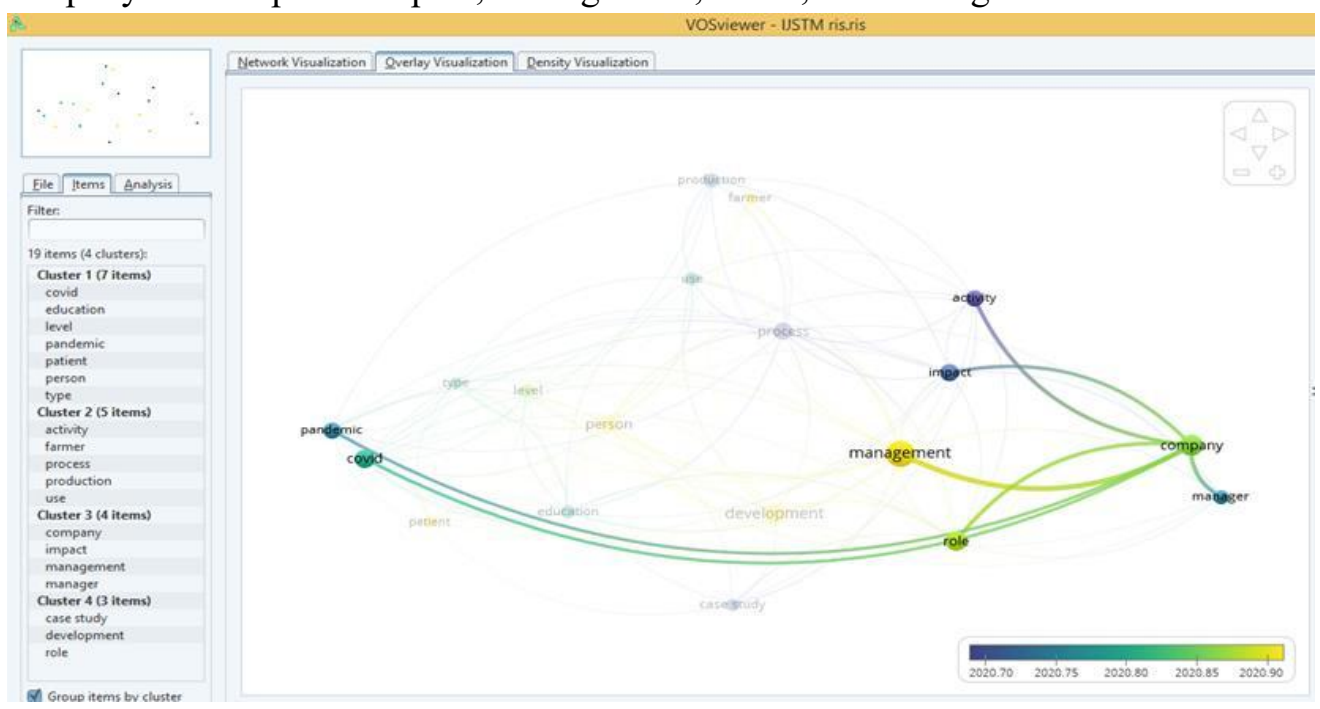

Fig 5. Cluster 3: Company 


\section{Cluster 4: Case Study}

This fourth cluster is related to Case Study. In cluster 4, the topic closest to Case Study is the topic of Development and Role.

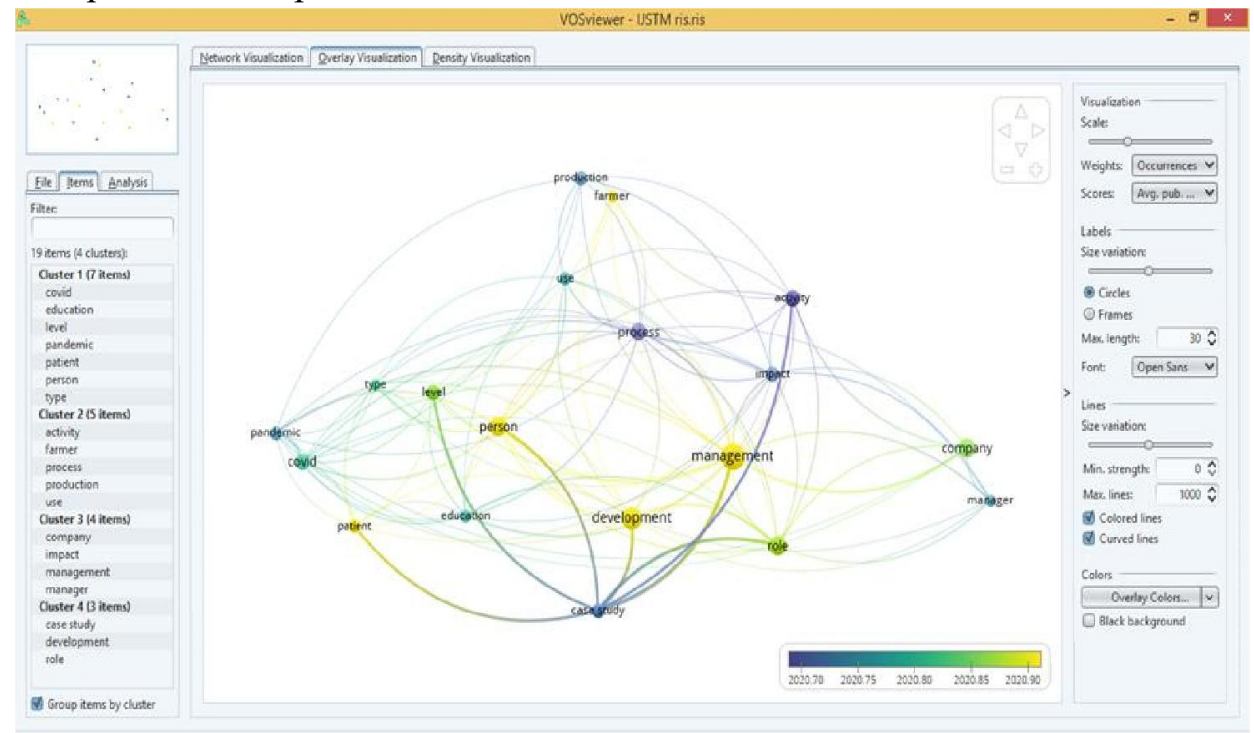

Fig 6. Cluster 4: Case Study

\section{CONCLUSION}

Within 3 (three) years of the establishment of the journal IJSTM (International Journal of Science, Technology \& Management) has shown progress. 514 authors and the number of affiliated countries including China, Malaysia and India. Over time, the number of institutions and affiliated countries will increase. Because scientific articles have become a necessity in the academic world. The more scientific articles that are made, the greater the number of articles published in the IJSTM Journal..

\section{REFERENCES}

[1] Arifin, MZ, Jalal, F., \& Makmuri. (2021). Bibliometric Analysis and Visualization of Blended Learning Research Trends with PoP and VOS Viewer. Turkish Journal of Computer and Mathematics Education.

[2] Donthu, N., Gremler, DD, Kumar, S., \& Pattnaik, D. (2020). Mapping of Journal of Service Research Themes: A 22-Year Review. Journal of Service Research. https://doi.org/10.1177/1094670520977672

[3] Donthu, N., Kumar, S., \& Pattnaik, D. (2020). Forty-five years of Journal of Business Research: A bibliometric analysis. Journal of Business Research. https://doi.org/10.1016/j.jbusres.2019.10.039.

[4] Donthu, N. (2021). How to conduct a bibliometric analysis: An overview and guidelines. Journal of Business Research. ttps://doi.org/10.1016/j.jbusres.2021.04.070. 
[5] Gaviria-Marin, M., Merigo, JM, \& Popa, S. (2018). Twenty years of the Journal of Knowledge Management: a bibliometric analysis. Journal of Knowledge Management. https://doi.org/10.1108/JKM-10-2017-0497.

[6] Goksu, I., Ozkaya, E., \& Gunduz, A. (2020). The content analysis and bibliometric mapping of CALL journal. Computer Assisted Language Learning. https://doi.org/10.1080/09588221.2020.1857409.

[7] Kessler, J. (1994). The Bibliotheque Nationale de France project:

Access or expediency? Journal of Librarianship and Information Science. https://doi.org/10.1177/096100069402600302

.[8] Sajovic, I., Tomc, HG, \& Podgornik, BB (2018). Bibliometric study and mapping of a journal in the field of visualization and computer graphics.

COLLNET Journal of Scientometrics and Information Management. https://doi.org/10.1080/09737766.2018.1453677

.[9] van Eck, NJ, \& Waltman, L. (2010). Survey software: VOSviewer, a computer program for bibliometric mapping. Scientometrics. https://doi.org/10.1007/s11192-009-0146-3 